\title{
Technical, Regulatory and Economic Measures to Abate Vehicular Emissions in Urban Areas in Indian Context
}

\author{
T.P.Meikandaan, M.Hemapriya, G.Kannan
}

\begin{abstract}
Air quality emergency in urban communities is mostly because of vehicular emanations. Transportation frameworks are expanding all over the place and the enhancements in innovation are deficient to neutralize development. Transport sections contribute a large offer to natural emissions (around 70 percent). One of these CO pollutants is the considerable emission from the part of the vehicle that contributes 90 percent of the total discharge. Next to $\mathrm{CO}$ are hydrocarbons. It is certainly surprising to see that the transport segment's contribution to particulate pollution is as small as 3.5 percent; most of the SPM is created as a result of residual re-suspension from which PM10 is the most visible air poison. NOx is another significant indicator of air quality. Each of these circumstances shows that air contamination is becoming a major issue in the Indian setting and that there is a fundamental need to develop sound condition and increase the level of research around the world. This investigation is a survey of an evaluation model of produced poisons and powerful techniques to reduce air contamination due to street transportation.
\end{abstract}

Key words : Air pollution, vehicular emissions, Vehicular pollution, control strategies

\section{INTRODUCTION}

Crumbling air quality is a significant ecological issue in numerous Indian urban communities. Air contamination levels in a large portion of the Indian urban areas surpass the national and world wellbeing association rules and compromise human wellbeing and personal satisfaction. Albeit urban air quality in a large portion of the mechanical nations has been controlled somewhat during the previous two decades in numerous urban communities it is compounding and turning into a significant danger to the wellbeing and welfare of individuals and nature. In the vast majority of the Indian urban communities the contamination loads are far above adequate levels and Delhi has procured the questionable qualification of being the second most dirtied city on the planet and contamination worry at other Metropolitan urban communities viz, Kolkatta, Mumbai and Chennai are on the expanding patterns.

Air pollution has local, regional and global effects. At local level, some of the air pollutants (like particulates, hydrocarbons, Nitrogen oxides, carbon monoxide) affect

Revised Manuscript Received on October 22, 2019.

T.P.Meikandaan, Department of Civil Engineering, Bharath Institute of Higher Education and Research, Chennai , India. Email: ganga_meik@yahoo.co.in

M.Hemapriya, Department of Civil Engineering, Bharath Institute of Higher Education and Research, Chennai , India. Email: meihemapriya@gmail.com

G.Kannan, Department of Civil Engineering, Bharath Institute of Higher Education and Research, Chennai , India. Email: kannang99@gmail.com human health. They are responsible for hundreds of thousands of deaths, respiratory, coronary and other diseases including cancer. At regional level, air pollutants like sulpher dioxide and oxides of nitrogen react with the moisture in the air to form sulphuric acid and nitric acid which are transported by winds (sometimes hundreds of Kilometers) before falling on earth by acid rain. Acid rain has environmental effects associated with damage to crops and acidification of soils and surface waters. Other environmental impacts include damage to buildings and structures, vegetation, forests, reduced visibility etc., The global warming pollutants (carbon-di oxide, methane, nitrogen oxide, etc) popularly known as green house gases results in climate change and global warming. Global warming affects human health, agriculture and rise in sea levels. The effects of climate change, heat waves, drought conditions etc, are already being felt in the recent years in the Indian sub continent.

Vehicles are responsible for fine particulates in the ambient air, Diesel vehicles and two stroke and three wheelers contribute to particulate emissions. While vehicles are responsible for about $20 \%$ of the particulate emissions in the ambient air, they are responsible for about 60 to $70 \%$ of PM10(Respirable particulate matter) in the ambient air. One of the major reasons for higher RSPM levels in Delhi and other cities is due to higher number of two stroke two wheelers and diesel vehicles.

\section{A. Vehicle Technology And Emissions}

Vehicle technology improvements can dramatically reduce pollutant emissions and improve fuel efficiency. Changes in engine technology can achieve very large reductions in pollutant emissions. Major advances in this area have come from engine modifications, exhaust after treatment devices (catalytic converters and trap oxidizers), on-board canisters, on-board diagnostics etc.,

In Indian cities, two wheelers are responsible for about $75 \%$ three wheelers for about $5 \%$, cars for about $10 \%$ and buses and trucks for about $10 \%$ of the total pollution loads (1). Health effects-wise, fine particulates are the most serious and studies indicate that two and three wheelers and diesel commercial vehicles in India contribute to more than $70 \%$ of the ambient fine particulates. While two and three wheelers and commercial vehicles are responsible for bulk of the pollutant emissions, their technology in India for reducing emissions needs to be improved. Most of the car manufacturers in India have foreign collaborations for new technologies.

This is however not true for heavy commercial vehicles and 
two and three wheelers. In contrast to passenger cars, the technology developments for two and three wheelers have to be done with indigenous efforts since ready made technologies for these vehicles are not available from abroad. Two and three wheelers are the mode of transport for majority of the population in India in contrast to the Western countries where two wheelers are the mode of entertainment. Hence technology development for these vehicles are of little interest to the western world. The sheer large numbers of two wheelers in India demands that the technology be up graded to reduce the air pollution in India cities. Technology wise, the commercial vehicle segment in India significant lags behind U.S, Europe and Japan. Electronic control is absent and the very concept of pollution control devices (catalytic converters, particulate traps, de-nox catalysts etc.,) has not yet entered the Indian market. The buses and trucks currently used in India have several disadvantages. They are not fuel efficient and confirm to only Euro-1 norms and are not passenger and driver friendly.

Status of vehicle technology in India

In the last two decades, the face of automobile industry in Indian has changed significantly. From being a protected and relatively small market, it has become a major international market with almost all the international giants opening production facilities in the country. The Indian automobile sector is dominated by two and three wheelers, followed by passenger cars and the commercial vehicles.

Such a management strategy will generally require

(A)Technical measures,

(B)Regulatory measures and

(C)Economic measures.

(A)TECHNICAL MEASURES

(i)Control of emissions at Pre-combustion stage

Control of emissions at Pre-combustion stage can be successfully achieved by change in fuel. Alternative fuels commonly considered for vehicular use are natural gas (in compressed or liquefied form), liquefied petroleum gas (LPG), methanol (made from natural gas, coal or bio mass), ethanol(made from molasses, sugar cane etc), vegetable oils, bio diesel, hydrogen and various blends such as gasohol(mixtures of gasoline and ethanol)

Natural gas $(\mathrm{CNG})$ vehicles: In response to emerging epidemiological evidence of the toxicity of gasoline and diesel emissions there is growing interest in substituting conventional auto fuels with natural gas in cities where ambient air quality is considered unsatisfactory. Natural gas is a clean burning alternative fuel with a significant potential for reducing harmful emissions from vehicles. Over 1.5 million vehicles run on natural gas world wide. Argentina, Italy, Pakistan, Brazil, United States, Canada,NewZeland and Russia are some of the countries operating large number of natural gas vehicles.

Emission benefits of CNG buses compared to conventional Diesel buses is shown in Table (1)

Table 1 Emission Benefits of Replacing Conventional Diesel with CNG in Buses

\begin{tabular}{|l|c|c|c|}
\hline \multirow{2}{*}{ Fuel } & \multicolumn{3}{|c|}{ Pollution Parameter } \\
\cline { 2 - 4 } & $\mathrm{CO}$ & $\mathrm{NOx}$ & $\mathrm{PM}$ \\
\hline Diesel & $2.4 \mathrm{~g} / \mathrm{km}$ & $21 \mathrm{~g} / \mathrm{km}$ & $0.38 \mathrm{~g} / \mathrm{km}$ \\
\hline CNG & $0.4 \mathrm{~g} / \mathrm{km}$ & $8.9 \mathrm{~g} / \mathrm{km}$ & $\begin{array}{c}0.012 \\
\mathrm{~g} / \mathrm{km}\end{array}$ \\
\hline & & & 97 \\
\hline \% Reduction & 84 & 58 & 9 \\
\hline
\end{tabular}

Source : Frailey et al. (2000) as referred in World Bank (2001b: 2).

The comparison between emission results of Gasoline, CNG and LPG vehicles with three way Catalyst is shown in Table (2)

Table 2 : Emission results of Gasoline, CNG and LPG vehicles

\begin{tabular}{|l|c|c|c|}
\hline \multirow{2}{*}{$\begin{array}{l}\text { Emission, } \\
\mathrm{g} / \mathrm{km}\end{array}$} & \multicolumn{3}{|c|}{ Pollution Parameter } \\
\cline { 2 - 4 } & Petrol & LPG & $\mathrm{CNG}$ \\
\hline $\mathrm{CO}$ & 1.12 & 0.91 & 0.45 \\
\hline $\mathrm{HC}$ & 0.15 & 0.12 & 0.36 \\
\hline $\mathrm{NOx}$ & 0.15 & 0.21 & 0.13 \\
\hline $\mathrm{SPM}$ & 0.015 & 0.005 & 0.025 \\
\hline
\end{tabular}

\section{(ii)Control of emissions at combustion stage:}

This is one of the strategy to control outflows at burning stage where motor adjustments are required i.e by making upgrades in the present vehicle innovation.

Vehicle innovation enhancements can significantly diminish poison emanations and improve eco-friendliness. Changes in motor innovation can accomplish enormous decreases in toxin discharges. Such changes are best when joined in new vehicles. The most widely recognized way to deal with consolidating such changes has experienced the foundation of vehicle outflow gauges. The foundation of outflow models has been a significant catalyst for innovative work of motor plans and contamination control advancements. Significant advances around there have originated from motor adjustments, exhaust after treatment gadgets (exhaust systems and trap oxidizers), on-board canisters, on-board diagnostics and so forth., Major decrease in vehicle poison emanations are conceivable through changes in innovation at moderately minimal effort, and, as a rule with a net reserve funds in life cycle cost because of better eco-friendliness and diminished support necessities.

While two and three wheelers and business vehicles are liable for main part of the toxin discharges, their innovation in India for lessening emanations should be improved.

\section{(iii)Control of emissions at post combustion stage}

As the discharge enactments are turning out to be increasingly stringent, these interior changes in the motor are not satisfactory in controlling outflows from vehicles.

A helpful choice to control outflows further inside the motor is to diminish them rather with consequent treatment of the fumes gas, This permits the burning procedure inside the chamber to be enhanced for best power and efficiency instead of for most reduced discharges. 
The idea overseeing after treatment gadgets is basic and straight forward. The emanating stream from the motor is carried into contact with a synergist surface, where the contamination discharges and the oxygen staying in the fumes gases come into contact bringing about the change of wellbeing influencing toxins into innocuous poisons. Until this point in time, the vehicle exhaust after treatment gadgets are by a long shot, the best and financially savvy technique for diminishing basic poisons to the levels required by stringent outflows principles.

\section{(B)REGULATARY MEASURES}

\section{(i)Emission standards and regulations}

Stopping the growth in motor vehicle use is neither feasible nor desirable, given the economic and other benefits of mobility. Strategy to abate vehicular pollution in an urban area requires policy measures which can be broadly classified as command and control measures for curtailing vehicular pollution mainly rely on regulatory options -emission standards for new vehicles, fuel quality standards or specification, testing and certification rules for new vehicles, inspection requirements for in use vehicles.etc.,

Vehicle emission standards can be classified as either "technology-forcing" or "technology- following " emission standards. Technology - forcing standards are at a level that though technically feasible, have not yet been demonstrated in practice. Manufacturers must research, develop and commercialize new technologies to meet these standards. Technology-following standards involve emission levels that can be met with demonstrated technology

The past, present and future Euro standards for heavy duty diesel vehicles recommended for implementation by Mashelkar committee are detailed in Table (3)

\begin{tabular}{|l|c|c|c|c|c|c|}
\hline \multirow{2}{*}{$\begin{array}{l}\text { Type of } \\
\text { Emission }\end{array}$} & \multicolumn{7}{|c|}{ Standards (g.km) } \\
\cline { 2 - 7 } & 1992 & 1996 & $\begin{array}{c}2000 \\
\text { Euro1 }\end{array}$ & $\begin{array}{c}\text { Euro } \\
2\end{array}$ & $\begin{array}{c}\text { Euro } \\
3\end{array}$ & $\begin{array}{c}\text { Euro } \\
4\end{array}$ \\
\hline $\mathrm{CO}$ & 14 & 11.2 & 4.5 & 4.0 & 2.10 & 1.5 \\
\hline $\mathrm{HC}$ & 3.5 & 2.4 & 1.1 & 1.1 & 0.66 & 0.46 \\
\hline $\mathrm{NOx}$ & 18 & 14.4 & 8.0 & 7.0 & 5.00 & 3.5 \\
\hline $\mathrm{SPM}$ & & & 0.36 & 0.15 & 0.10 & 0.02 \\
\hline
\end{tabular}

(ii)Controlling emissions from in-use vehicles-inspection and maintenance programmes

To mitigate the adverse effects of emissions from vehicles, stringent emission norms are being proposed for all new vehicles. However, they will only help to control emissions from new vehicles and have no effect on the emissions of large number of "in-use vehicles. Large number of "in-use" vehicles. Effective I \& M programme is therefore of primary importance to bring down the emission standards and also the procedures for I \& $\mathrm{M}$ in India. Following Two types of organizations exist for inspection and maintenance programmes viz. centralized and decentralized
Halting the development in engine vehicle utilize is neither plausible nor attractive, given the financial and different advantages of expanded versatility. The test, at that point, is to deal with the development of vehicles in order to amplify the advantages while limiting its unfriendly effect on the earth.

Specialized measures including vehicles and fills can significantly decrease air contamination and other unfriendly natural effects of street transport . Anyway specialized measures without anyone else's input are not adequate to ensure ecologically satisfactory results as time goes on. They should be supported and enhanced by administrative and financial motivations/discentives..

Economic measures such as emission taxes, fuel taxes, congestion pricing, environmental excise duty, differential taxation etc afford large scope for encouraging non polluting behavior. For example, emission taxes are expected to result in vehicle owners buying lower polluting vehicles, maintaining their vehicles better and change their travel to reduce vehicle usage etc. Economic measures encourage vehicle manufacturers to invest in Research and Development (R \&D) for developing better vehicles with lower emissions. Similarly effective congestion pricing is capable of directing traffic flows toward socially optimum levels and educe vehicular emissions significantly.

(i)Congestion pricing to reduce vehicular emissions

The slow movement of motor vehicles on congested roads results in higher fuel consumption and increased rates of pollutant emissions. Vehicles under stop and start conditions use about three times more fuel and cause about three times more pollutant emissions than those in free flowing traffic.

Charging for the use of roads to control congestion is not a new idea. Many cities around the world have implemented the concept either manually or electronically (eg. Singapore, Hongkong, London, Cambridge, Paris, Los Angeles, etc,) Many more cities have initiated detailed studies and are in the process of doing so. The area Licensing scheme of Singapore area wide congestion scheme of London, toll rings to reduce congestion in city centres introduced in Los Angles and France have been effective in reducing congestion. Some of these schemes with necessary modifications can be implemented effectively in India to reduce congestion and ambient air pollution.

\section{CONCLUSION}

A management strategy for a long term measure will generally require

i)Technical measures,

ii)Regulatory measures and

iii)Economic measures.

Under the topic Regulatory measures, the vehicular emissions can be controlled as below.

(i)Strict implementation on Emission standards and regulations

(ii)Controlling emissions from in-use vehicles by carrying out effective inspection and maintenance programmes

Economic measures :Stopping the growth in motor vehicle

\section{(C)ECONOMIC MEASURES}


use is neither feasible nor desirable, given the economic and other benefits of increased mobility. The challenge, then, is to manage the growth of vehicles so as to maximize the benefits while minimizing its adverse impact on the environment. Technical measures involving vehicles and fuels can dramatically reduce air pollution and other adverse environmental impacts of road transport. However technical measures by themselves are not sufficient to guarantee environmentally acceptable outcomes over the long run. They need to be encouraged and supplemented by regulatory and economic incentives

\section{REFERENCES}

1. Iyappan L., Dayakar P., Identification of landslide prone zone for coonoortalukusing spatial technology, International Journal of Applied Engineering Research,V-9,I-22,PP-5724-5732,Y-2014.

2. Kumar J., Sathish Kumar K., Dayakar P.,Effect of microsilica on high strength concrete, International Journal of Applied Engineering Research,V-9,I-22,PP-5427-5432,Y-2014.

3. Dayakar P., Vijay Ruthrapathi G., Prakesh J., Management of bio-medical waste, International Journal of Applied Engineering Research,V-9,I-22,PP-5518-5526,Y-2014.

4. Swaminathan N., Dayakar P., Resource optimization in construction project, International Journal of Applied Engineering Research,V-9,I-22,PP-5546-5551,Y-2014

5. Venkat Raman K., Dayakar P., Raju K.V.B.,An experimental study on effect of cone diameters in penetration test on sandy soil, International Journal of Civil Engineering and Technology,V-8,I-8,PP-1581-1588,Y-2017.

6. Saritha B., Chockalingam M.P.,Photodradation of malachite green DYE using TIO2/activated carbon composite,International Journal of Civil Engineering and Technology,V-8,I-8,PP-156-163,Y-2017

7. Shendge R.B., Chockalingam M.P., Saritha B., Ambica A.,Swat modelling for sediment yield: A case study of Ujjani reservoir in Maharashtra, India,International Journal of Civil Engineering and Technology,V-9,I-1,PP-245-252,Y-2018

8. Chockalingam M.P., Balamurgan V.,Modernisation of an existing urban road-sector in Chennai, a case study report,International Journal of Civil Engineering and Technology,V-8,I-8,PP-1457-1467,Y-2017

9. Saritha B., Chockalingam M.P.,Adsorption study on removal of basic dye by modified coconut shell adsorbent, International Journal of Civil Engineering and Technology,V-8,I-8,PP-1370-1374,Y-2017

10. Saritha B., Chockalingam M.P.,Adsorptive removal of heavy metal chromium from aqueous medium using modified natural adsorbent,International Journal of Civil Engineering and Technology,V-8,I-8,PP-1382-1387,Y-2017

11. Chockalingam M.P., Palanivelraja S.,Retrospective analysis of a theoretical model used for forecasting future air quality near the north Chennai thermal power plant,International Journal of Civil Engineering and Technology,V-8,I-8,PP-1457-1467,Y-2017

12. Saritha B., Chockalingam M.P.,Photodegradation of methylene blue dye in aqueous medium by $\mathrm{Fe}-\mathrm{AC} / \mathrm{TiO} 2$ Composite,Nature Environment and Pollution Technology,V-17,I-4,PP-1259-1265,Y-2018

13. Shendge R.B., Chockalingam M.P., Kaviya B., Ambica A.,Estimates of potential evapotranspiration rates by three methods in upper Bhima Basin, In Maharashtra, India,International Journal of Civil Engineering and Technology,V-9,I-2,PP-475-480,Y-2018

14. Shendge R.B., Chockalingam M.P.,The soil and water assessment tool for Ujjani Reservoir,International Journal of Mechanical Engineering and Technology,V-9,I-2,PP-354-359,Y-2018

15. Shendge R.B., Chockalingam M.P.,A review on soil and water assessment tool,International Journal of Mechanical Engineering and Technology,V-9,I-2,PP-347-353,Y-2018

16. Sachithanandam P., Meikandaan T.P., Srividya T.,Steel framed multi storey residential building analysis and design,International Journal of Applied Engineering Research,V-9,I-22,PP-5527-5529,Y-2014

17. Meikandaan T.P., Ramachandra Murthy A.,Study of damaged RC beams repaired by bonding of CFRP laminates, International Journal of Civil Engineering and Technology,V-8,I-2,PP-470-486,Y-2017
18. Meikandaan T.P., Ramachandra Murthy A.,Retrofittng of reinforced concrete beams using GFRP overlays,International Journal of Civil Engineering and Technology,V-8,I-2,PP-423-439,Y-2017

19. Meikandaan T.P., Ramachandra Murthy A.,Flexural behaviour of RC beam wrapped with GFRP sheets,International Journal of Civil Engineering and Technology,V-8,I-2,PP-452-469,Y-2017

20. Meikandaan T.P., Murthy A.R.,Experimental study on strengthening of rc beams using glass Fiber,International Journal of Civil Engineering and Technology,V-9,I-11,PP-959-965,Y-2018

21. Meikandaan T.P., Hemapriya M.,Use of glass FRP sheets as external flexural reinforcement in RCC Beam,International Journal of Civil Engineering and Technology,V-8,I-8,PP-1485-1501,Y-2017

22. Saraswathy R., Saritha B.,Planning of integrated satellite township at Thirumazhisai,International Journal of Applied Engineering Research,V-9,I-22,PP-5558-5560,Y-2014

23. Saritha B., Ilayaraja K., Eqyaabal Z.,Geo textiles and geo synthetics for soil reinforcement,International Journal of Applied Engineering Research,V-9,I-22,PP-5533-5536,Y-2014

24. Ambica A., Saritha B., Changring G., Singh N B., Rajen M., Salman Md.,Analysis of groundwater quality in and around Tambaram taluk, Kancheepuram district,International Journal of Civil Engineering and Technology,V-8,I-8,PP-1362-1369,Y-2017

25. Arunya A., Sarayu K., Ramachandra Murthy A., Iyer N.R.,Enhancement of durability properties of bioconcrete incorporated with nano silica,International Journal of Civil Engineering and Technology,V-8,I-8,PP-1388-1394,Y-2017

26. Ilayaraja K., Krishnamurthy R.R., Jayaprakash M., Velmurugan P.M., Muthuraj S.,Characterization of the 26 December 2004 tsunami deposits in Andaman Islands (Bay of Bengal, India),Environmental

Sciences,V-66,I-8,PP-2459-2476,Y-2012

27. Ilayaraja K.,Morphometric parameters of micro watershed in Paravanar sub-basin, Cuddalore District,International Journal of Civil Engineering and Technology,V-8,I-8,PP-1444-1449,Y-2017

28. Ilayaraja K., Singh R.K., Rana N., Chauhan R., Sutradhar N.,Site suitability assessment for residential areas in south Chennai region using remote sensing and GIS techniques,International Journal of Civil Engineering and Technology,V-8,I-8,PP-1468-1475,Y-2017

29. Ilayaraja K., Reza W., Kumar V., Paul S., Chowdhary R.,Estimation of land surface temperature of Chennai metropolitan area using Landsat images,International Journal of Civil Engineering and Technology,V-8,I-8,PP-1450-1456,Y-2017

30. Chitra R.,Experimental study on beam using steel fiber and latex,International Journal of Civil Engineering and Technology,V-8,I-8,PP-1395-1403,Y-2017

31. Chitra R.,Analysis of traffic and management at Kovilambakkam intersection,International Journal of Civil Engineering and Technology,V-8,I-8,PP-1433-1443,Y-2017

32. Aswathy M.,Experimental study on light weight foamed concrete,International Journal of Civil Engineering and Technology,V-8,I-8,PP-1404-1412,Y-2017

33. Aswathy M.,Wastewater treatment using constructed wetland with water lettuce (Eichornia Crasipies),International Journal of Civil Engineering and Technology,V-8,I-8,PP-1413-1421,Y-2017

Kiruthiga K., Anandh K.S., Gunasekaran K, Assessment of influencing factors on improving effectiveness and productivity of construction engineers, 2015, International Journal of Applied Engineering Research, V - 10,I -17,p -13849-13854

\section{AUTHORS PROFILE}

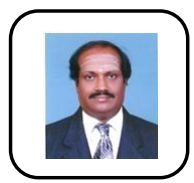

T.P.Meikandaan, Associate Professor Department of Civil Engineering, Bharath Institute of Higher Education and Research, Chennai , India.

M.Hemapriya, Assistant ProfessorDepartment of Civil Engineering, Bharath Institute of Higher Education and Research, Chennai , India. 
G.Kannan , Mtech Student,Department of Civil Engineering, Bharath Institute of Higher Education and Research, Chennai , India. 